\title{
Hepcidin and sports anemia
}

\author{
Wei-Na Kong ${ }^{1,2}$, Guofen Gao ${ }^{1}$ and Yan-Zhong Chang ${ }^{1 *}$
}

\begin{abstract}
Iron is an important mineral element used by the body in a variety of metabolic and physiologic processes. These processes are highly active when the body is undergoing physical exercises. Prevalence of exercise-induced iron deficiency anemia (also known as sports anemia) is notably high in athletic populations, particularly those with heavy training loads. The pathogenesis of sports anemia is closely related to disorders of iron metabolism, and a more comprehensive understanding of the mechanism of iron metabolism in the course of physical exercises could expand ways of treatment and prevention of sports anemia. In recent years, there have been remarkable research advances regarding the molecular mechanisms underlying changes of iron metabolism in response to physical exercises. This review has covered these advances, including effects of exercise on duodenum iron absorption, serum iron status, iron distribution in organs, erythropoiesis, and hepcidin's function and its regulation. New methods for the treatment of exercise-induced iron deficiency are also discussed.
\end{abstract}

Keywords: Iron metabolism, Exercise, Anemia, Hepcidin

\section{Introduction}

Iron is an essential trace element in the human body. It is important for the synthesis of hemoglobin and oxygen delivery, and plays a key role in the electron transport chain as well as the production of energy in mitochondria $[1,2]$. Many of these functions are directly related to physical exercises. There is a high rate in athletes, particularly those with heavy training loads, of being iron deficient, which is resulted from iron losses in hemolysis, hematuria, sweating and gastrointestinal bleeding during sports training [3-6]. Exercise-induced iron deficiency anemia, also known as sports anemia, leads to a decline of athletes' performances and other physiologic dysfunctions [2,7]. A more comprehensive understanding of the mechanisms of iron deficiency related to sports activities may help improving the methods of diagnoses and treatments of iron related-disorders in athletes.

\section{Effects of intensive exercise on iron metabolism} Iron metabolism involves three main aspects: iron absorption from the diet in the duodenal enterocytes, iron usage in the erythroid precursors, and iron storage and reutilization in the hepatocytes and tissue macrophages.

\footnotetext{
* Correspondence: chang7676@163.com

'Laboratory of Molecular Iron Metabolism, College of Life Science, Hebei Normal University, Shijiazhuang 050016, Hebei Province, P. R. China Full list of author information is available at the end of the article
}

Effects of intensive exercise on intestinal iron absorption Iron in the diet can be found in two forms, non-heme (inorganic) and heme (organic). Radioactive studies of heme and non-heme iron absorption showed rather low values in athletes involved in intensive physical activities [8]. Studies on rats also found that iron absorption apparently decreased in the strenuously exercised rats as compared to the sedentary controls [9]. However, the molecular mechanisms of regulation on the altered iron absorption during exercise remained unclear. Over the past decade, the findings of several important molecules involved in iron homeostasis, including divalent metal transporter 1 (DMT1), ferroportin1 (FPN1), heme-carrier protein 1 (HCP1), hephaestin (HP) and ceruloplasmin $(\mathrm{Cp})$, have helped to illuminate the mechanism of decreased iron absorption in athletes.

Intestinal iron absorption is a tightly regulated process (Figure 1). Inorganic $\mathrm{Fe}^{3+}$ cannot be absorbed well, and duodenal cytochrome B561 (DcytB), a heme-containing enzyme at the apical surface of the enterocytes, converts $\mathrm{Fe}^{3+}$ into $\mathrm{Fe}^{2+}$ for better absorption [10]. $\mathrm{Fe}^{2+}$ is transported across the apical membrane of enterocytes by the transmembrane transporter DMT1, which is also known as DCT1 or Nramp2 [11]. Different combinations of the alternative $5^{\prime}$ and $3^{\prime}$ exons (1A or $1 \mathrm{~B}$ and IRE or non-IRE, respectively) of DMT1 gene can specify up to four distinct mRNAs encoding four different DMT1 [12]. All these 


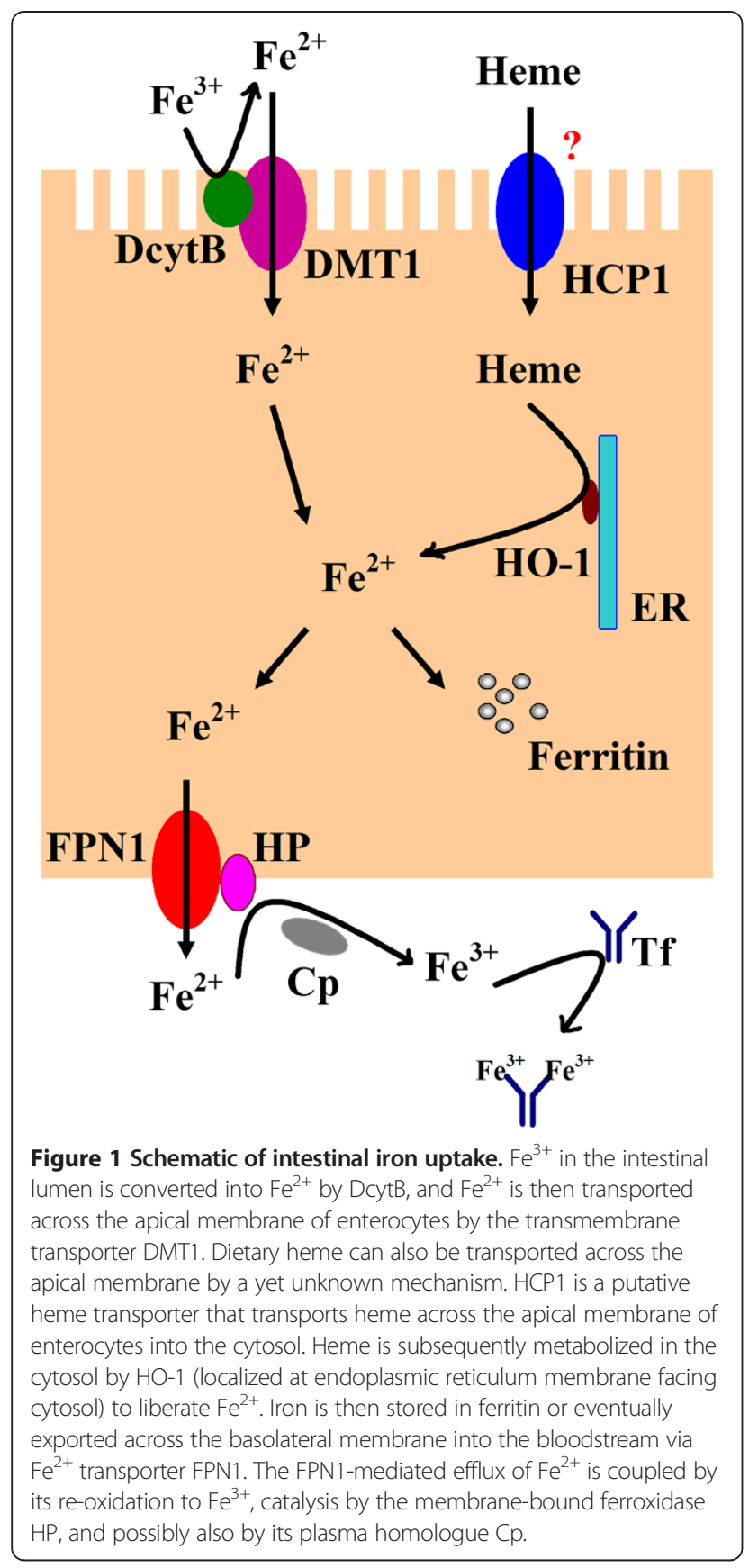

DMT1 isoforms function as iron transporters with equivalent transport efficiency [13]. The mechanism of heme iron absorption is still not well understood. It has been suggested that HCP1, a high-affinity folate influx transporter, is responsible for the uptake of heme into the gut cells from the intestinal lumen [14]. Then heme is catabolized in enterocytes by heme oxygenase-1 (HO-1), producing free iron, biliverdin and carbon monoxide [15]. Iron is then stored in ferritin [16] or transferred out across the basolateral membrane by an integral membrane protein FPN1 [17] in cooperation with HP [18], and possibly also involves its plasma homologue Cp [19]. Our recent studies found that the expression of duodenal DMT1, HCP1 and FPN1 decreased in strenuously exercised rats as compared to the control group [20]. This might be the reason why iron absorption, including both non-heme and heme iron, is reduced in athletes after intensive exercise.

\section{Effects of intensive exercise on iron usage by erythroid precursors}

Erythroid cells are the major iron-utilizing cells in the body. It is generally believed that transferrin and transferrin receptor (TfR) mediated iron delivery is the main pathway of iron uptake in erythroid cells [21,22]. The number of TfR on cell membrane is an important factor to reflect the cell's ability to uptake iron from transferrin. In addition, a soluble form of the TfR (sTfR) has been identified in animal and human serums. sTfR is released by erythroblasts [23] and reticulocytes [24], and has been established as a quantitative marker of cellular TfR. Levels of TfR on cell membrane and sTfR in serum are both considered as indicators for the marrow's erythropoietic activity.

Studies by Qian et al. [25] found that the average number of surface TfR on erythroblasts significantly increased in the strenuously exercised rats as compared to the controls. A significant increase of the rate of radioactive iron uptake by the erythroblasts of the exercised rats was also observed. The sTfR levels significantly increased as well in the exercised rats when compared with the sedentary group [26]. These results implied that intensive exercise could lead to an increase in erythropoietic activity of the marrow.

\section{Effects of intensive exercise on iron storage and reutilization}

Most of the body iron is stored in parenchymal cells and macrophages of the liver. When the body iron demand increases, iron storage in organs and tissues decreases. Intensive exercise can lead to an increase in erythropoietic activity of the marrow [25,26], and the synthesis of hemoglobin requires a large amount of iron. Therefore, intensive exercise could induce a reduction of iron stores in liver. Studies of Liu et al. [20] and Qian et al. [25] confirmed the above hypothesis. They found that exercise induced a significant decrease of the iron concentration in liver. However, other reports showed that hepatic iron level increased significantly with acute exercise [27,28]. The contradictory results could come from different training methods, exercise intensity, or length. Hemolysis has been reported to occur in a variety of exercises including swimming, cycling and running $[29,30]$. When erythrocyte destruction occurs intravascularly, it results in release of hemoglobin into the bloodstream [31]. Then the free 
hemoglobin is rapidly bound by haptoglobin and cleared from the circulation by parenchymal cells or macrophages of the liver [32]. It has been observed that the haptoglobin level in serum decreased after exercise [31]. Therefore, some of iron is redistributed from red blood cells to the liver due to hemolysis, which might explain why in some studies an increased hepatic iron level resulted from intensive exercises could be observed.

\section{Sports anemia and hepcidin}

Although exercise can increase erythropoietic activity in marrow [25], it was found that erythrocyte numbers, haemoglobin levels and haematocrit values were significantly decreased after intensive training $[20,26]$. This observation may be resulted from the reduced iron absorption in small intestine and the decreased iron export to the circulation from parenchymal cells and macrophages. Many studies have reported that significant decreases in a series of serum iron status indicators, including serum iron, transferrin saturation and serum ferritin, were observed in both human and animal models following intensive training [20,33-35]. This suggested that the amount of serum iron transferred to bone marrow was reduced after extensive exercise, which may cause the iron concentration in bone marrow cannot meet the demand of the accelerated erythropoietic process. As a result, the increased loss of red blood cells and the insufficient production of new red blood cells together would lead to the occurrence of anemia. However, the regulatory mechanism in iron metabolism that leads to the decreased iron absorption in small intestine and the trapping of iron in liver are unknown. Hepcidin, the principal iron-regulatory hormone responsible for the maintenance of iron homeostasis, controls the absorption of dietary iron and the distribution of iron among organs and tissues in the body [36]. Therefore, the decreased iron absorption and increased hepatic iron stores observed in the exercised rats may closely relate to the hepatic hepcidin expression.

\section{Effects of intensive exercise on the expression of hepcidin} In recent years, many studies on the function of hepcidin in sports anemia have been reported. A $72 \mathrm{~h}$ timeline of hepcidin expression post-exercise was assessed, which showed that the hepcidin level significantly elevated at 3 , 6 and $24 \mathrm{~h}$ post-exercise, and then declined from there, reaching baseline at $72 \mathrm{~h}$ post-exercise [37,38]. These results revealed the association of hepcidin expression with the intensive exercise. Instead of using a single exercise stimulus, studies from our laboratory detected the accumulative effects of intensive exercise on hepcidin expression by having the rats take strenuous treadmill running for 5 weeks. Our results showed that the hepatic hepcidin mRNA increased significantly in the exercised rats, and those rats were diagnosed as sports anemia after 5 weeks of intensive exercise [20]. These findings were consistent with the results observed in human [39].

\section{Hepcidin causes the reduction of duodenal iron absorption and trapping of intracellular iron during exercise}

Nemeth et al. [40] have demonstrated that hepcidin can decrease the functional activity of FPN1 by binding to it directly, resulting in its internalization and degradation, and thereby blocking cellular iron efflux. It was also demonstrated that the triggering of FPN1 degradation by hepcidin in hepatocytes could lead to decreased iron export and increased retention of cellular iron [41]. Treatment of macrophages with hepcidin dramatically decreased the FPN1 protein level and reduced the efflux of iron after erythrophagocytosis [42,43]. Administration of His-tagged recombinant hepcidin resulted in significant reduction of duodenal FPN1 expression in rats [44]. Therefore, it can be concluded that hepcidin limits the release of iron from hepatocytes, macrophages and enterocytes by decreasing FPN1 expression and increasing its degradation. In addition, both in vitro and in vivo studies have demonstrated that the duodenal DMT1 level decreases following hepcidin treatment $[45,46]$. Further studies showed that the decreased expression of DMT1 by hepcidin was caused by ubiquitin-dependent proteasome degradation in Caco-2 cells (a human intestinal cell line) [47]. These results suggest that hepcidin not only controls iron release to the circulation, but also regulates iron absorption in the intestine.

Taken together, it can be inferred that the increased hepcidin expression after exercise results in the degradation of iron transporters such as DMT1 and FPN1, causing the reduction of iron absorption from small intestine and the trapping of iron in hepatocytes and macrophages. Therefore, it is very likely that the frequently observed iron deficiency in athletes is caused, at least in part, by the elevated hepcidin level. Some of the above speculations have been investigated in our previous studies. We found that hepatic hepcidin mRNA significantly increased in rats trained with strenuous exercise, which was associated with an obvious decrease in duodenal DMT1 and FPN1 expression [20]. However, whether the expression of FPN1 in parenchymal cells or macrophages of the liver alters during exercise remains to be investigated in the future studies.

\section{Hepcidin expression in moderate exercise}

It is well known that strenuous exercise usually leads to the development of sports anemia. In contrast, regular and moderate exercise training might be a promising, safe and economical method to help improve body iron status. Our previous results showed that the levels of 
serum iron and transferrin saturation in moderately exercised rats were significantly higher than that of the controls [48]. This in turn induced an increased iron transport from blood to bone marrow to synthesize hemoglobin and erythrocytes, resulting in enhanced oxygen-carrying capacity [48].

Studies also investigated the changes of hepcidin expression level during moderate exercise, and found that the moderate exercise did not induce but decreased hepcidin expression [48,49]. Studies further demonstrated that the expression of DMT1 and FPN1 in duodenum of the moderately exercised rats increased significantly as compared to the controls, suggesting that moderate exercise may increase duodenal iron absorption [48]. These results, from a different aspect, imply that hepcidin plays an important role during exercise.

\section{Hepcidin regulation by exercise}

Hepcidin is produced primarily by hepatocytes. Other tissues and cells, such as macrophages, have been shown to express hepcidin as well, though at a much lower level [50]. So far, it has been demonstrated that hepcidin expression can be influenced by inflammation [51], body iron status [52], erythropoiesis [53], as well as hypoxia [54] (Figure 2).

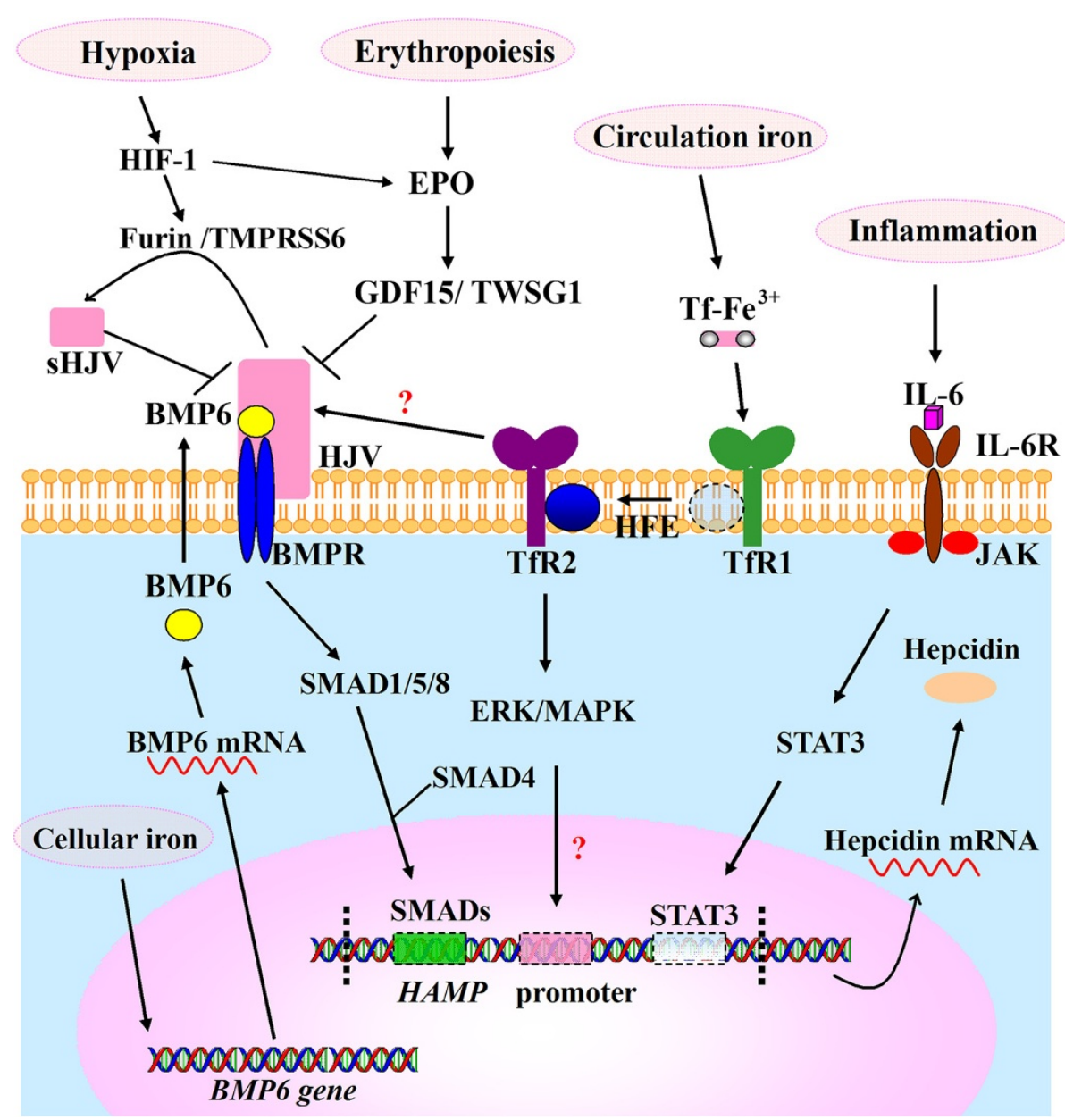

Figure 2 Molecular mechanisms of hepcidin regulation. So far, three molecular pathways are found to be involved in the regulation of hepcidin, JAK/STAT3, BMP/SMAD and HFE/TRR2 pathways. Inflammatory stimuli, such as IL-6, induce hepcidin synthesis through the JAK/STAT3 pathway. Hepatic cellular iron can increase the expression of BMP-6. The released BMP6 then interacts with BMPR and HJV to form a complex and activates the SMAD pathway. The SMAD pathway involves phosphorylation of SMAD1, 5, and 8 (pSMADs), formation of pSMADs/SMAD4 complex, and the subsequent translocation of this complex to the nucleus to activate the expression of the hepcidin gene. Extracellular Tf- $\mathrm{Fe}^{2+}$ mediates a second iron signal. When the serum transferrin saturation increases, Tf-Fe ${ }^{2+}$ displaces HFE from TfR1. HFE then interacts with TfR2 to form the HFE/TfR2 complex. The HFE/TfR2 complex activates hepcidin transcription via HJV/BMP/SMAD and/or ERK/MAPK signaling pathway. Furthermore, HJV is subjected to cleavage by furin and TMPRSS6 to form a soluble HJV (SHJV), which can selectively inhibit BMP-induced hepcidin expression. Furin and TMPRSS6 can be regulated by hypoxia via HIF-1. Erythropoiesis may control hepcidin expression by EPO production. EPO subsequently stimulates GDF15 expression, which acts together with TWSG1 to inhibit hepatic hepcidin expression by inhibiting the BMP/SMAD pathway. 


\section{Hepcidin regulation by inflammation during exercise}

A variety of studies have demonstrated that exercise induces notable physiological changes in the immune system [55]. Strenuous exercise can induce a dramatic increase in the levels of pro-inflammatory cytokines and inflammation-responsive cytokines [56]. Interleukin-6 (IL-6) is the major cytokine that was produced at a significant higher amount in response to exercise than other cytokines [57,58], while the contracting muscles contribute to most of the IL- 6 production in the circulation in response to exercise [57,59].

Hepcidin synthesis was markedly induced by infection and inflammation [51,60], and IL-6 itself is sufficient to induce hepcidin expression during inflammation [61]. Significant higher amount of hepatic hepcidin mRNA was detected 3 to $6 \mathrm{~h}$ after IL- 6 stimulation, which indicates that the production of IL- 6 in contracting skeletal muscles results in the exercise-induced hepcidin increase. Studies by Peeling et al. [38] support this hypothesis as it was found that hepcidin levels elevated $3 \mathrm{~h}$ after the peak production of IL- 6 induced by exercise. In addition, animals treated with cyclosporin A, a calcineurin inhibitor to blunt plasma IL-6 during exercise, showed lower hepcidin levels as compared to the exercised group without cyclosporin A treatment [62]. These results suggest that IL-6 is involved in the exercise-induced increase of hepcidin expression. Furthermore, it has been demonstrated that the stimulatory effect of IL-6 on hepcidin expression exhibits at the transcriptional level. Hepcidin expression is directly induced by IL-6 through the activation of the janus kinase/signal transducer and activator of transcription-3 (JAK/STAT3) signaling pathway during inflammatory stimulation [63-65].

\section{Hepcidin regulation by iron status during exercise}

How iron regulates the expression of hepcidin has been a hot area of study in this field. By studying the naturally occurring mutations in humans and using transgenic mouse models, valuable information has been obtained regarding the key molecules involved in the regulation of hepcidin expression by circulating iron and hepatic stored iron. These molecules include HFE (HLA2-linked hemochromatosis gene) [66,67], transferrin receptor 2 (TfR2) [68-70], hemojuvelin (HJV) [71] and bone morphogenetic protein (BMP) [72]. A possible model on the regulation of hepcidin by iron is proposed based on these results (Figure 2). Briefly, hepcidin expression is regulated by hepatic cellular iron stores through Bone morphogenetic protein 6 (BMP6) signaling. BMP6 is an activating ligand for BMP receptor (BMPR), and its level reflects the level of hepatic iron stores. When liver iron concentration is high, the production of hepatocyte BMP6 is increased. Then, the released BMP6 from the hepatocyte forms a complex with BMPR and HJV.
Binding of BMP6 to BMPR controls the transcription of hepcidin by activating the SMAD pathway. The liver uses transferrin saturation as an extracellular iron sensor. When the serum transferrin saturation increases, HFE is dislodged from its binding site on TfR1, and then interacts with TfR2 to form the HFE/TfR2 complex. This complex participates in the hepcidin regulation though activation of the extracellular signalregulated kinases/the mitogen activated protein kinase (ERK/MAPK) pathway and/or HJV/BMP/SMAD pathway [36,52,73-76].

HJV plays a central role in the regulation of hepatic hepcidin expression. HJV acts as a coreceptor for BMP to increase the sensitivity of BMPR to BMP, and various hepcidin regulatory pathways seem to be converged at this protein (Figure 2). Recent researches showed that HJV is not only highly expressed in liver, but also in skeletal muscles. Studies from our laboratory found the levels of HJV mRNA in liver and skeletal muscle were remarkably higher in the exercised rats than in the controls [20]. Thus, hepcidin expression may also be induced by the elevation of HJV during exercise. However, the underlying mechanism of HJV-regulated hepcidin expression in response to sport remains to be explored.

\section{Hepcidin regulation by erythropoiesis during exercise}

Studies by Qian et al. [25] and Tian et al. [26] both indicated that extensive exercise could lead to an increase in erythropoietic activity of bone marrow. It has also been demonstrated that increased erythropoiesis can suppress hepcidin expression significantly [51]. However, the relationship between increased erythropoiesis and decreased hepcidin expression and the molecules involved remain unclear. Erythropoietin (EPO), an endogenous hormone produced primarily by kidney, is a key regulator of erythropoiesis. EPO promotes the proliferation and differentiation of the erythroid progenitor cells [77]. Increases in serum EPO concentration have been observed in athletes [78], and many studies also reported that hepatic hepcidin expression strongly reduced by EPO treatment $[79,80]$. Therefore, EPO has been considered to be a potential mediator of hepcidin regulation. The in vitro studies by Pinto et al. [81] indicated that the EPO suppression on hepcidin expression was achieved by modulating the $\mathrm{C} / \mathrm{EBP} \alpha \mathrm{mRNA}$ and decreasing its protein levels, thereby resulting in significant changes in the transcription of hepcidin mRNA. However, this hypothesis has not been confirmed in vivo. Studies in animal models found that the suppression of hepcidin expression by EPO administration could be recovered by using the inhibitors of erythropoiesis via irradiation or posttransfusion polycythemia [82,83]. These results suggest that EPO decreases hepcidin transcription only when the erythropoiesis is active. Therefore, the suppression of hepcidin expression 
was not directly mediated by EPO, and other erythropoietic factors may be involved.

Growth differentiation factor 15 (GDF15), a member of the transforming growth factor-beta superfamily, is produced by erythroid cells during erythroblast maturation to promote differentiation of erythroid [84]. It has been found that GDF15 significantly increased immediately after a $246-\mathrm{km}$ foot-race, and then it showed a decline at $48 \mathrm{~h}$ post-exercise, but was still above the baseline level. Erythroid-specific production of GDF15 is fully dependent on EPO stimulation [85]. Therefore, GDF15 might provide a link between erythropoiesis and hepatic hepcidin regulation. In fact, GDF15 has been identified as a hepcidin-suppression factor that expresses at high levels in thalassemia patients with ineffective erythropoiesis. In cultured hepatocytes, high level of GDF15 has also been found to suppress hepcidin expression [86]. Twisted gastrulation (TWSG1), an erythroid signaling molecule that expresses at early stages during erythropoiesis, was proposed to act together with GDF15 to inhibit hepatic hepcidin expression through inhibiting the BMP-dependent activation of SMAD-mediated signal transduction [87]. However, this proposed mechanism is still controversial. Casanovas et al. [88] found that hepatic hepcidin mRNA expression was not altered in GDF15 $5^{-/-}$mice under steady state conditions or upon phlebotomy as compared to wild-type mice, which suggests that GDF15 is not involved in the down-regulation of hepcidin under steady state conditions or in response to blood loss in mice. Therefore, whether GDF15 is involved in the hepcidin regulation by erythropoiesis during exercise needs to be further studied.

\section{Hepcidin regulation by hypoxia during exercise}

Many studies have demonstrated that training athletes at high altitude may significantly increase their $\mathrm{VO}_{2} \max$ and $\mathrm{RBC}$ mass and thereby improve their endurance performance $[89,90]$. Further studies found that the adaptation in iron metabolism will appear under high altitude and hypoxia conditions in mountaineers. Under hypoxia conditions, serum duodenal DMT1 and FPN1 mRNA increased and hepcidin level decreased. These changes would result in increased dietary iron uptake and iron release from iron stores to ensure a sufficient iron supply for hypoxia-induced erythropoiesis [91].

The mechanism of hepcidin suppression by the hypoxia at high altitude is also unclear. It is likely that hypoxia-inducible transcription factor (HIF), the master regulator of the systemic and cellular adaptation to hypoxia, plays a role in hepcidin regulation. Peyssonnaux et al. [92] proposed that HIF regulates hepcidin expression directly via transcriptional suppression. However, this could not be confirmed in the isolated hepatocytes [93], and other indirect pathways by which HIF regulates hepcidin expression may exist. It has been found that HIF could regulate renal and hepatic EPO synthesis directly under hypoxia [94], and the activation of hepatic HIF itself without the concomitant increase in EPO transcription did not suppress hepcidin expression [95]. Therefore, the regulation of HIF on hepcidin may be mediated by affecting the EPO synthesis. Taken together with the above mentioned association between EPO induction and elevated serum GDF15 level [91], it can be inferred that HIF-associated suppression of hepcidin may occur indirectly through EPO-induced erythropoiesis and its subsequent signaling via GDF15 [95]. Furthermore, HIF was reported to induce the production of furin and transmembrane serine proteinase TMPRSS6 (also known as matriptase-2), two proteases that mediate the release of soluble hemojuvelin (s-HJV) by cleaving HJV off from the cell membrane $[96,97]$. s-HJV was found to competitively inhibit BMP-induced hepcidin expression [98,99]. Therefore, HIF may also suppress hepcidin expression by increasing the breakdown of $\mathrm{HJV}$ and inhibiting the BMP-induced hepcidin expression.

\section{Hepcidin in the premenopausal female athletes}

It is believed that female athletes may experience higher risk of sports anemia than male athletes due to the iron losses in some physiologic processes, such as menstruation [100]. However, it has been found that erythropoiesis induced by blood loss could lead to a decrease in hepcidin expression, thereby increasing iron level in the body. By using the serum enzyme-linked immunosorbent assay, it was found that healthy women had lower serum hepcidin levels than healthy men [101]. Animal studies also found that bleeding provoked by repetitive phlebotomies was associated with a dramatic decrease in hepatic hepcidin level [51]. However, the precise mechanism on hepcidin regulation associated with sex differences is not clear. Studies by Ikeda et al. showed that the female sex hormone, estrogen, can stimulate hepcidin expression in a GPR30-BMP6-dependent pathway [102]. In contrast, testosterone can suppress hepcidin expression potently via testosterone/AR/SMAD [103] or testosterone/EGF/EGFR signaling pathways [104]. Based on these above results, it puzzles to find that the serum hepcidin level in women is lower than that in men. We hypothesized that physiological loss of blood in pre-menopausal women had a suppressive effect on hepcidin transcription, which may counteract the stimulating effect of estrogen on hepcidin expression to some extent. If menstruation in the female athletes does not exist, they still would develop iron deficiency anemia much rapider than the male athletes because of the high level of hepcidin induced by estrogen.

\section{Methods to measure the hepcidin level}

Because of the important functions of hepcidin in athlete's iron homeostasis, a reliable assay to measure hepcidin 
levels in the body fluids of athletes should be developed. However, for many years, it has been difficult to detect hepcidin by the conventional immunochemical assay. This is mainly due to the problems in generating specific anti-hepcidin antibodies in animals because of low immunogenicity of the short hepcidin peptides [79]. Hepcidin is synthesized by the liver in the form of an 84 amino-acid pro-peptide, but it is detected in the plasma as three isoforms including hepcidin-20, -22, and -25 [105]. The hepcidin-20 and -22 isoforms play no role in the regulation of iron metabolism, but they can interfere with the quantification of hepcidin-25, because the antibodies used in the immunoassays can react with all of three hepcidin isoforms.

In recent years, substantial progress has been made in the measurement of hepcidin. These methods can be divided into two main methodologies. The first one is mass spectrometry (MS)-based hepcidin measurement, which has the advantage of distinguishing hepcidin-25, -22, and -20 in various body fluids, including serum and urine samples, but it requires relatively expensive equipment [106-109]. The second method, immunochemical assays including competitive radioimmunoassay (RIA) [110], competitive enzyme-linked immunosorbent assay (ELISA) $[107,111]$ and dual-monoclonal sandwich ELISA [112], is suitable for the large-scale quantification of serum hepcidin because of its low cost and high-throughput features, but these assays usually measure the amount of all three hepcidin isoforms [112].

\section{Treatment of sports anemia}

\section{The use of iron-supplementary}

For iron deficiency anemia, iron supplement therapy is a relatively safe and economical method, but the efficacy of iron supplement is often very low. Previous studies have demonstrated that iron supplementation can lead to the increase of serum ferritin without accompanied by the increase in hemoglobin concentration [113]. On the other hand, increased iron stores in the body are a common finding in elite athletes who have used long-term iron supplementation, putting the athletes at an increasing risk of developing iron overload-related diseases [114]. The combination of exercise-induced decrease of iron absorption in duodenum and increase of iron retention in hepatocytes and macrophages may be responsible for the above observation. Therefore, investigations to explore new methods for the treatment of sports anemia should be initiated.

\section{The use of hepcidin antagonists}

The recent advances in the molecular mechanisms of iron regulation reveal that the elevated hepcidin expression is a key factor in the development of sports anemia. Hepcidin inhibits iron absorption in enterocytes and causes iron sequestration in hepatocytes and macrophages [36]. Therefore, using hepcidin antagonists to modulate hepcidin expression is a novel alternative therapy for the treatment of sports anemia. Although no such therapy has yet been available, several candidates are currently under development.

\section{Methods to neutralize hepcidin's activity}

Monoclonal antibodies of hepcidin Cooke et al. [115] generated anti-hepcidin human antibodies as a potential therapeutic for the treatment of anemia of inflammation (AI), which has the similar iron-related disorders to sports anemia. They found that these antibodies can increase the availability of serum iron and lead to enhanced red cell hemoglobinization both in mouse and cynomolgus monkey models of AI. However, hepcidin antibodies may reduce the natural clearance of hepcidin in the circulation and thus result in further hepcidin accumulation.

Small-molecule antagonists of hepcidin Fung et al. [116] identified a small molecule, named fursultiamine, which inhibits the hepcidin-FPN1 interaction. They found that fursultiamine directly interfered with hepcidin binding to FPN1, thereby preventing hepcidin-induced FPN1 ubiquitination, endocytosis and degradation. This allowed continuous cellular iron export despite of the presence of hepcidin. Studies by Schwoebel et al. [117] found another anti-hepcidin compound, NOX-H94, which can also protect FPN1 from hepcidin-induced degradation.

\section{Methods to decrease hepcidin expression}

In addition to directly interfering with hepcidin activity, therapies can be effective by targeting erythropoiesis pathway, inflammatory pathway, or HJV/BMP/SMAD signaling pathway to decrease the hepcidin production.

EPO doping EPO is the primary signal that triggers erythropoiesis in anemic and hypoxic conditions. Therefore, EPO has been investigated as a drug to increase oxygen transport and improve athletic endurance capacity [118]. EPO has been frequently used by athletes as a performanceenhancing agent [119]. In 1990, the International Olympic Committee (IOC) prohibited the use of EPO in sports. Without considering its legality, EPO doping administration has the potential of correcting some misregulations in iron metabolism of athletes. Previous studies in our lab observed that administration of recombinant human erythropoietin (rHuEPO) induced a dramatic reduction in hepcidin expression, which is closely associated with the increased intestinal iron absorption and macrophage iron release [53,120]. However, athletes, who use EPO to enhance their performance, are taking great health risks. Elevated haematocrit and dehydratation during intense exercise may induce high blood viscosity, which is often associated with high blood 
cardiovascular problems, such as hypertension, heart hypertrophy and brain vascular congestion [121].

Anti-IL6 antibodies and STAT modulators Anti-cytokine therapeutics, such as anti-IL-6 antibodies, can block the induction of hepcidin and improve anemia [122,123]. AG490, a small molecule of STAT3 inhibitor, can suppress hepcidin transcription and increase serum iron levels in mice by inhibiting the JAK/STAT signaling pathway [124]. CO-releasing molecules can also inhibit the IL-6-induced hepcidin expression through inhibition of the STAT3 pathway [125]. However, the anti-cytokine therapy may lead to an increased risk for severe infections due to the impaired host defense [126].

BMP modulators As mentioned above, s-HJV decreases hepcidin expression by competing with $\mathrm{HJV}$ and interfering with BMP signaling [98]. Studies by Theurl et al. [127] demonstrated that inhibition of hepcidin expression by using the soluble hemojuvelin-Fc (sHJV.Fc) in a rat model of AI resulted in the mobilization of iron stores, increase of serum iron levels, stimulation of erythropoiesis, and correction of anemia. In addition, inhibition of BMP type I receptor signaling by small molecules, such as dorsomorphin, was also effective in alleviating iron deficiency anemia. Dorsomorphin can block BMP-mediated SMAD1/ $5 / 8$ phosphorylation, reduce hepcidin expression and raise serum iron levels [128]. Heparin, another potent inhibitor of hepcidin expression, can induce a strong reduction in serum hepcidin both in animal models and humans, which finally led to an increase in serum iron levels [129]. It functions likely by sequestering BMP6 and blocking of SMAD signaling [129]. However, since BMP pathway plays a variety of important functions in the body, the use of BMP modulators may have various adverse effects. BMP modulators as potential drugs to reduce hepcidin expression should have a great specificity.

\section{Conclusions}

Iron is an essential trace element required to support the physical functions in human body. However, iron deficiency is commonly found in strenuous exercised athletes. In addition to those well-known processes of iron loss, such as hemolysis, hematuria, sweating and gastrointestinal bleeding, exercise-induced up-regulation of hepcidin expression might be the main reason that results in iron deficiency in athletes. Taken together of our work with others' reports, we infer that the increased hepcidin inhibits both brush border iron uptake and basolateral export through the down-regulation of key iron transporters, DMT1 and FPN1. In hepatocytes and macrophages, hepcidin decreases FPN1 expression and results in a decreased iron export and cellular iron retention. Reduced intestinal iron absorption, sequestered iron in hepatocytes and macrophages, and elevated iron demand for erythropoiesis after extensive exercise can lead to a low-iron status, indicated by low serum iron concentration, transferrin saturation and markedly decreased non-heme iron concentration in some tissues. If the amount of iron in marrow could not meet the needs for erythropoiesis during exercise, iron deficiency anemia will be developed. Therefore, iron homeostasis will be destroyed after the prolonged strenuous exercise, which does harm athletes' performance and health. Molecules IL-6, HJV, EPO and HIF were found to be involved in the exercise-induced alteration of hepcidin expression. The possible regulatory mechanism for each molecule was discussed in this review. However, our current understanding of the detailed mechanisms on exercise-induced alteration of iron metabolism is still incomplete, and further studies are needed. Recent advances regarding the drugs that can decrease hepcidin expression were summarized in this review, which will provide some insights into the development of potential therapeutics for treatment of sports anemia in the future.

\section{Abbreviations \\ DMT1: Divalent metal transporter 1; FPN1: Ferroportin1; HCP1: Heme-carrier protein; HP: Hephaestin; Cp: Ceruloplasmin; DcytB: Duodenal cytochrome B561; HO: Heme oxygenase; TfR: Transferring receptor; IL-6: Interleukin-6; JAK: Janus kinase; STAT3: Signal transducer and activator of transcription-3; HJV: Hemojuvelin; BMP: Bone morphogenetic protein; ERK: Extracellular signal-regulated kinase; MAPK: Mitogen activated protein kinase; EPO: Erythropoietin; GDF15: Growth differentiation factor 15; HIF: Hypoxia-inducible transcription factor; TWSG1: Twisted gastrulation; ELISA: Enzyme-linked immunosorbent assay; rHuEPO: Recombinant human erythropoietin; Al: Anemia of inflammation; RIA: Radioimmunoassay.}

\section{Competing interests}

The authors declare that they have no competing interests.

\section{Authors' contributions}

Y-ZC conceived the review and participated in design and discussion. W-NK wrote the main parts of the manuscript and participated in discussion. GG participated in discussion and writing of the manuscript. All authors read and approved the final manuscript.

\section{Acknowledgements}

This project was supported by the National Natural Science Foundation of China (31340064, 10979025), the Natural Science Foundation of Hebei Province (C2012205082) and the Scientific Research Fund of Hebei Provincial Education Department (Q2012036).

\section{Author details}

${ }^{1}$ Laboratory of Molecular Iron Metabolism, College of Life Science, Hebei Normal University, Shijiazhuang 050016, Hebei Province, P. R. China. ${ }^{2}$ Bioreactor and Protein Drug Research and Development Center of Hebei Universities, Hebei Chemical \& Pharmaceutical College, Shijiazhuang 050026, Hebei Province, P. R. China.

Received: 26 September 2013 Accepted: 3 February 2014 Published: 14 April 2014

\section{References}

1. Speich M, Pineau A, Ballereau F: Minerals, trace elements and related biological variables in athletes and during physical activity. Clin Chim Acta 2001, 312:1-11. 
2. Stoltzfus RJ: Iron-deficiency anemia: reexamining the nature and magnitude of the public health problem. Summary: implications for research and programs. J Nutr 2001, 131:697S-700S. discussion 700S-701S

3. Janakiraman K, Shenoy S, Sandhu JS: Intravascular haemolysis during prolonged running on asphalt and natural grass in long and middle distance runners. J Sport Sci 2011, 29:1287-1292.

4. McInnis MD, Newhouse IJ, von Duvillard SP, Thayer R: The effect of exercise intensity on hematuria in healthy male runners. Eur J Appl Physiol O 1998, 79:99-105.

5. DeRuisseau KC, Cheuvront SN, Haymes EM, Sharp RG: Sweat iron and zinc losses during prolonged exercise. Int J Sport Nutr Exe 2002, 12:428-437.

6. Babic Z, Papa B, Sikirika-Bosnjakovic M, Prkacin I, Misigoj-Durakovic M, Katicic M: Occult gastrointestinal bleeding in rugby player. J Sport Med Phys Fit 2001, 41:399-402.

7. Brownlie T, Utermohlen V, Hinton PS, Haas JD: Tissue iron deficiency without anemia impairs adaptation in endurance capacity after aerobic training in previously untrained women. Am J Clin Nutr 2004, 79:437-443.

8. Ehn L, Carlmark B, Hoglund S: Iron status in athletes involved in intense physical activity. Med Sci Sport Exer 1980, 12:61-64.

9. Ruckman KS, Sherman AR: Effects of exercise on iron and copper metabolism in rats. J Nutr 1981, 111:1593-1601.

10. McKie AT, Barrow D, Latunde-Dada GO, Rolfs A, Sager G, Mudaly E, Mudaly M Richardson C, Barlow D, Bomford A, Peters TJ, Raja KB, Shirali S, Hediger MA Farzaneh F, Simpson RJ: An iron-regulated ferric reductase associated with the absorption of dietary iron. Science 2001, 291:1755-1759.

11. Gunshin H, Mackenzie B, Berger UV, Gunshin Y, Romero MF, Boron WF, Nussberger S, Gollan JL, Hediger MA: Cloning and characterization of a mammalian proton-coupled metal-ion transporter. Nature 1997, 388:482-488.

12. Hubert N, Hentze MW: Previously uncharacterized isoforms of divalent metal transporter (DMT)-1: implications for regulation and cellular function. Proc Natl Acad Sci U S A 2002, 99:12345-12350.

13. Mackenzie B, Takanaga H, Hubert N, Rolfs A, Hediger MA: Functional properties of multiple isoforms of human divalent metal-ion transporter 1 (DMT1). Biochem J 2007, 403:59-69.

14. Le Blanc S, Garrick MD, Arredondo M: Heme carrier protein 1 transports heme and is involved in heme-Fe metabolism. Am J Physiol-Cell Ph 2012, 302:C1780-1785.

15. Gottlieb Y, Truman M, Cohen LA, Leichtmann-Bardoogo Y, Meyron-Holtz EG: Endoplasmic reticulum anchored heme-oxygenase 1 faces the cytosol. Haematologica 2012, 97:1489-1493.

16. Munro HN, Linder MC: Ferritin: structure, biosynthesis, and role in iron metabolism. Physiol Rev 1978, 58:317-396.

17. Donovan A, Brownlie A, Zhou Y, Shepard J, Pratt SJ, Moynihan J, Paw BH, Drejer A, Barut B, Zapata A, Law, TC, Brugnara C, Lux SE, Pinkus GS, Pinkus JL, Kingsley PD, Palis J, Fleming MD, Andrews NC, Zon LI: Positional cloning of zebrafish ferroportin1 identifies a conserved vertebrate iron exporter. Nature 2000, 403:776-781

18. Yeh KY, Yeh M, Glass J: Interactions between ferroportin and hephaestin in rat enterocytes are reduced after iron ingestion. Gastroenterology 2011, 141:292-299. 299 e291.

19. Cherukuri S, Potla R, Sarkar J, Nurko S, Harris ZL, Fox PL: Unexpected role of ceruloplasmin in intestinal iron absorption. Cell Metab 2005, 2:309-319.

20. Liu YQ, Chang YZ, Zhao B, Wang HT, Duan XL: Does hepatic hepcidin play an important role in exercise-associated anemia in rats? Int J Sport Nutr Exe 2011, 21:19-26.

21. Levy JE, Jin O, Fujiwara Y, Kuo F, Andrews NC: Transferrin receptor is necessary for development of erythrocytes and the nervous system. Nat Genet 1999, 21:396-399.

22. Cooperman SS, Meyron-Holtz EG, Olivierre-Wilson H, Ghosh MC, McConnel JP, Rouault TA: Microcytic anemia, erythropoietic protoporphyria, and neurodegeneration in mice with targeted deletion of iron-regulatory protein 2. Blood 2005, 106:1084-1091

23. Shintani N, Kohgo Y, Kato J, Kondo H, Fujikawa K, Miyazaki E, Niitsu Y: Expression and extracellular release of transferrin receptors during peripheral erythroid progenitor cell differentiation in liquid culture. Blood 1994, 83:1209-1215.

24. R'Zik S, Loo M, Beguin Y: Reticulocyte transferrin receptor (TfR) expression and contribution to soluble TfR levels. Haematologica 2001, 86:244-251.

25. Qian ZM, Xiao DS, Tang PL, Yao FY, Liao QK: Increased expression of transferrin receptor on membrane of erythroblasts in strenuously exercised rats. J Appl Physiol 1999, 87:523-529.
26. Tian Y, Zhao J, Zhao B, Gao Q, Xu J, Liu D: The ratio of sTfR/ferritin is associated with the expression level of TfR in rat bone marrow cells after endurance exercise. Biol Trace Elem Res 2012, 147:261-266.

27. Kaptanoglu B, Turgut G, Genc O, Enli Y, Karabulut I, Zencir M, Turgut S: Effects of acute exercise on the levels of iron, magnesium, and uric acid in liver and spleen tissues. Biol Trace Elem Res 2003, 91:173-178.

28. Navas FJ, Cordova A: Iron distribution in different tissues in rats following exercise. Biol Trace Elem Res 2000, 73:259-268.

29. Selby GB, Eichner ER: Endurance swimming, intravascular hemolysis, anemia, and iron depletion. New perspective on athlete's anemia. Am J Med 1986, 81:791-794.

30. Telford RD, Sly GJ, Hahn AG, Cunningham RB, Bryant C, Smith JA: Footstrike is the major cause of hemolysis during running. J Appl Physiol 2003, 94:38-42.

31. Peeling P, Dawson B, Goodman C, Landers G, Wiegerinck ET, Swinkels DW Trinder D: Training surface and intensity: inflammation, hemolysis, and hepcidin expression. Med Sci Sport Exer 2009, 41:1138-1145.

32. Kong WNDX, Shi ZH, Chang YZ: Iron metabolism in the mononuclear phagocyte system. Proc Natl Acad Sci U S A 2008, 18:1197-1202.

33. Magazanik A, Weinstein $Y$, Dlin RA, Derin M, Schwartzman S, Allalouf D: Iron deficiency caused by 7 weeks of intensive physical exercise. Eur J Appl Physiol O 1988, 57:198-202.

34. Merkel D, Huerta M, Grotto I, Blum D, Rachmilewitz E, Fibach E, Epstein Y, Shpilberg O: Incidence of anemia and iron deficiency in strenuously trained adolescents: results of a longitudinal follow-up study. J Adolescent Health 2009, 45:286-291.

35. Reinke S, Taylor WR, Duda GN, von Haehling S, Reinke P, Volk HD, Anker SD, Doehner W: Absolute and functional iron deficiency in professional athletes during training and recovery. Int J Cardiol 2012, 156:186-191.

36. Ganz T: Hepcidin and iron regulation, 10 years later. Blood 2011, 117:4425-4433.

37. Roecker L, Meier-Buttermilch R, Brechtel L, Nemeth E, Ganz T: Iron-regulatory protein hepcidin is increased in female athletes after a marathon. Eur J Appl Physiol 2005, 95:569-571.

38. Peeling P, Dawson B, Goodman C, Landers G, Wiegerinck ET, Swinkels DW, Trinder D: Effects of exercise on hepcidin response and iron metabolism during recovery. Int J Sport Nutr Exe 2009, 19:583-597.

39. Auersperger I, Knap B, Jerin A, Blagus R, Lainscak M, Skitek M, Skof B: The effects of 8 weeks of endurance running on hepcidin concentrations, inflammatory parameters, and iron status in female runners. Int I Sport Nutr Exe 2012, 22:55-63.

40. Nemeth E, Tuttle MS, Powelson J, Vaughn MB, Donovan A, Ward DM, Ganz T, Kaplan J: Hepcidin regulates cellular iron efflux by binding to ferroportin and inducing its internalization. Science 2004, 306:2090-2093.

41. Ramey G, Deschemin JC, Durel B, Canonne-Hergaux F, Nicolas G, Vaulont S: Hepcidin targets ferroportin for degradation in hepatocytes. Haematologica 2010, 95:501-504.

42. Knutson MD, Oukka M, Koss LM, Aydemir F, Wessling-Resnick M: Iron release from macrophages after erythrophagocytosis is up-regulated by ferroportin 1 overexpression and down-regulated by hepcidin. Proc Natl Acad Sci U S A 2005, 102:1324-1328.

43. Delaby C, Pilard N, Goncalves AS, Beaumont C, Canonne-Hergaux F: Presence of the iron exporter ferroportin at the plasma membrane of macrophages is enhanced by iron loading and down-regulated by hepcidin. Blood 2005, 106:3979-3984.

44. Yeh KY, Yeh M, Glass J: Hepcidin regulation of ferroportin 1 expression in the liver and intestine of the rat. Am J Physiol-Gastr L 2004, 286:G385-394.

45. Chung B, Chaston T, Marks J, Srai SK, Sharp PA: Hepcidin decreases iron transporter expression in vivo in mouse duodenum and spleen and in vitro in THP-1 macrophages and intestinal Caco-2 cells. J Nutr 2009, 139:1457-1462.

46. Mena NP, Esparza A, Tapia V, Valdes P, Nunez MT: Hepcidin inhibits apical iron uptake in intestinal cells. Am J Physiol-Gastr L 2008, 294:G192-198.

47. Brasse-Lagnel C, Karim Z, Letteron P, Bekri S, Bado A, Beaumont C: Intestinal DMT1 cotransporter is down-regulated by hepcidin via proteasome internalization and degradation. Gastroenterology 2011, 140:1261-1271. e1261.

48. Liu YQ, Duan XL, Chang YZ, Wang HT, Qian ZM: Molecular analysis of increased iron status in moderately exercised rats. Mol Cell Biochem 2006, 282:117-123.

49. Troadec MB, Laine F, Daniel V, Rochcongar P, Ropert M, Cabillic F, Perrin M, Morcet J, Loreal O, Olbina G, Westerman M, Nemeth E, Ganz T, Brissot P: Daily regulation of serum and urinary hepcidin is not influenced by 
submaximal cycling exercise in humans with normal iron metabolism. Eur J Appl Physiol 2009, 106:435-443.

50. Nguyen NB, Callaghan KD, Ghio AJ, Haile DJ, Yang F: Hepcidin expression and iron transport in alveolar macrophages. Am J Physiol-Lung C 2006, 291:L417-425.

51. Nicolas G, Chauvet C, Viatte L, Danan JL, Bigard X, Devaux I, Beaumont C, Kahn A, Vaulont $S$ : The gene encoding the iron regulatory peptide hepcidin is regulated by anemia, hypoxia, and inflammation. J Clin Invest 2002, 110:1037-1044.

52. Ramos E, Kautz L, Rodriguez R, Hansen M, Gabayan V, Ginzburg Y, Roth MP, Nemeth E, Ganz T: Evidence for distinct pathways of hepcidin regulation by acute and chronic iron loading in mice. Hepatology 2011, 53:1333-1341.

53. Kong WN, Chang YZ, Wang SM, Zhai XL, Shang JX, Li LX, Duan XL: Effect of erythropoietin on hepcidin, DMT1 with IRE, and hephaestin gene expression in duodenum of rats. J Gastroenterol 2008, 43:136-143.

54. Chaston TB, Matak P, Pourvali K, Srai SK, McKie AT, Sharp PA: Hypoxia inhibits hepcidin expression in HuH7 hepatoma cells via decreased SMAD4 signaling. American journal of physiology Cell physiology 2011, 300:C888-895.

55. Pedersen BK, Hoffman-Goetz L: Exercise and the immune system: regulation, integration, and adaptation. Physiol Rev 2000, 80:1055-1081.

56. Ostrowski K, Rohde T, Asp S, Schjerling P, Pedersen BK: Pro- and anti-inflammatory cytokine balance in strenuous exercise in humans. J Physiol 1999, 515(Pt 1):287-291.

57. Pedersen BK, Steensberg A, Schjerling P: Exercise and interleukin-6. Curr Opin Hematol 2001, 8:137-141.

58. Margeli A, Skenderi K, Tsironi M, Hantzi E, Matalas AL, Vrettou C, Kanavakis E, Chrousos G, Papassotiriou I: Dramatic elevations of interleukin-6 and acute-phase reactants in athletes participating in the ultradistance foot race spartathlon: severe systemic inflammation and lipid and lipoprotein changes in protracted exercise. J Clin Endocr Metab 2005, 90:3914-3918.

59. Fischer CP: Interleukin-6 in acute exercise and training: what is the biological relevance? Exerc Immunol Rev 2006, 12:6-33.

60. Nemeth E, Valore EV, Territo M, Schiller G, Lichtenstein A, Ganz T: Hepcidin, a putative mediator of anemia of inflammation, is a type II acute-phase protein. Blood 2003, 101:2461-2463.

61. Nemeth E, Rivera S, Gabayan V, Keller C, Taudorf S, Pedersen BK, Ganz T: IL-6 mediates hypoferremia of inflammation by inducing the synthesis of the iron regulatory hormone hepcidin. J Clin Invest 2004, 113:1271-1276.

62. Banzet S, Sanchez H, Chapot R, Bigard X, Vaulont S, Koulmann N: Interleukin-6 contributes to hepcidin mRNA increase in response to exercise. Cytokine 2012, 58:158-161.

63. Wrighting DM, Andrews NC: Interleukin-6 induces hepcidin expression through STAT3. Blood 2006, 108:3204-3209.

64. Pietrangelo A, Dierssen U, Valli L, Garuti C, Rump A, Corradini E, Ernst M, Klein C, Trautwein C: STAT3 is required for IL-6-gp130-dependent activation of hepcidin in vivo. Gastroenterology 2007, 132:294-300.

65. Verga Falzacappa MV, Vujic Spasic M, Kessler R, Stolte J, Hentze MW, Muckenthaler MU: STAT3 mediates hepatic hepcidin expression and its inflammatory stimulation. Blood 2007, 109:353-358.

66. Corradini E, Garuti C, Montosi G, Ventura P, Andriopoulos B Jr, Lin HY, Pietrangelo A, Babitt $\mathrm{JL}$ : Bone morphogenetic protein signaling is impaired in an HFE knockout mouse model of hemochromatosis. Gastroenterology 2009, 137:1489-1497.

67. Papanikolaou G, Samuels ME, Ludwig EH, MacDonald ML, Franchini PL, Dube MP, Andres L, MacFarlane J, Sakellaropoulos N, Politou M, Nemeth E, Thompson J, Risler JK, Zaborowska C, Babakaiff R, Radomski CC, Pape TD, Davidas O, Christakis J, Brissot P, Lockitch G, Ganz T, Hayden MR, Goldberg YP: Mutations in HFE2 cause iron overload in chromosome 1q-linked juvenile hemochromatosis. Nat Genet 2004, 36:77-82.

68. Kawabata H, Fleming RE, Gui D, Moon SY, Saitoh T, O'Kelly J, Umehara Y, Wano Y, Said JW, Koeffler HP: Expression of hepcidin is down-regulated in TfR2 mutant mice manifesting a phenotype of hereditary hemochromatosis. Blood 2005, 105:376-381.

69. Wallace DF, Summerville L, Crampton EM, Frazer DM, Anderson GJ, Subramaniam VN: Combined deletion of Hfe and transferrin receptor 2 in mice leads to marked dysregulation of hepcidin and iron overload. Hepatology 2009, 50:1992-2000.

70. Nemeth E, Roetto A, Garozzo G, Ganz T, Camaschella C: Hepcidin is decreased in TFR2 hemochromatosis. Blood 2005, 105:1803-1806.

71. Niederkofler V, Salie R, Arber S: Hemojuvelin is essential for dietary iron sensing, and its mutation leads to severe iron overload. J Clin Invest 2005, 115:2180-2186.
72. Babitt JL, Huang FW, Wrighting DM, Xia Y, Sidis Y, Samad TA, Campagna JA, Chung RT, Schneyer AL, Woolf CJ, Andrews NC, Lin HY: Bone morphogenetic protein signaling by hemojuvelin regulates hepcidin expression. Nat Genet 2006, 38:531-539.

73. Corradini E, Meynard D, Wu Q, Chen S, Ventura P, Pietrangelo A, Babitt JL: Serum and liver iron differently regulate the bone morphogenetic protein 6 (BMP6)-SMAD signaling pathway in mice. Hepatology 2011, 54:273-284.

74. Meynard D, Kautz L, Darnaud V, Canonne-Hergaux F, Coppin H, Roth MP: Lack of the bone morphogenetic protein BMP6 induces massive iron overload. Nat Genet 2009, 41:478-481.

75. Zhang AS: Control of systemic iron homeostasis by the hemojuvelin-hepcidin axis. Adv Nutr 2010, 1:38-45.

76. Hentze MW, Muckenthaler MU, Galy B, Camaschella C: Two to tango: regulation of Mammalian iron metabolism. Cell 2010, 142:24-38.

77. Krantz SB: Erythropoietin. Blood 1991, 77:419-434.

78. Roecker L, Kowoll R, Fraszl W, Battal K, Brechtel L, Brachmann S, Meier-Buttermilch R, Gunga HC, Stangl A, Kiesewetter H: Observation of serum erythropoietin concentrations in female athletes for up to eight days after a marathon run. Clin Lab 2006, 52:511-513.

79. Nicolas G, Viatte L, Bennoun M, Beaumont C, Kahn A, Vaulont S: Hepcidin, a new iron regulatory peptide. Blood Cells Mol Dis 2002, 29:327-335.

80. Ashby DR, Gale DP, Busbridge M, Murphy KG, Duncan ND, Cairns TD, Taube DH, Bloom SR, Tam FW, Chapman R, Maxwell PH, Choi P: Erythropoietin administration in humans causes a marked and prolonged reduction in circulating hepcidin. Haematologica 2010, 95:505-508.

81. Pinto JP, Ribeiro S, Pontes H, Thowfeequ S, Tosh D, Carvalho F, Porto G: Erythropoietin mediates hepcidin expression in hepatocytes through EPOR signaling and regulation of C/EBPalpha. Blood 2008, 111:5727-5733.

82. Vokurka M, Krijt J, Sulc K, Necas E: Hepcidin mRNA levels in mouse liver respond to inhibition of erythropoiesis. Physiol Res 2006, 55:667-674.

83. Pak M, Lopez MA, Gabayan V, Ganz T, Rivera S: Suppression of hepcidin during anemia requires erythropoietic activity. Blood 2006, 108:3730-3735.

84. Ramirez JM, Schaad O, Durual $S$, Cossali D, Docquier M, Beris P, Descombes $P$, Matthes T: Growth differentiation factor 15 production is necessary for normal erythroid differentiation and is increased in refractory anaemia with ring-sideroblasts. Brit J Haematol 2009, 144:251-262.

85. Forejtnikovà $H$, Vieillevoye M, Zermati Y, Lambert M, Pellegrino RM, Guihard S, Gaudry M, Camaschella C, Lacombe C, Roetto A, Mayeux P, Verdier F: Transferrin receptor 2 is a component of the erythropoietin receptor complex and is required for efficient erythropoiesis. Blood 2010, 116:5357-5367.

86. Tanno T, Bhanu NV, Oneal PA, Goh SH, Staker P, Lee YT, Moroney JW, Reed CH, Luban NL, Wang RH, Eling TE, Childs R, Ganz T, Leitman SF, Fucharoen S, Miller $J$ : High levels of GDF15 in thalassemia suppress expression of the iron regulatory protein hepcidin. Nat Med 2007, 13:1096-1101.

87. Tanno T, Porayette P, Sripichai O, Noh SJ, Byrnes C, Bhupatiraju A, Lee YT, Goodnough JB, Harandi O, Ganz T, Paulson RF, Miller JL: Identification of TWSG1 as a second novel erythroid regulator of hepcidin expression in murine and human cells. Blood 2009, 114:181-186.

88. Casanovas G, Spasic MV, Casu C, Rivella S, Strelau J, Unsicker K, Muckenthaler MU: The murine growth differentiation factor 15 is not essential for systemic iron homeostasis in phlebotomized mice. Haematologica 2013, 98:444-447.

89. Son HJ, Kim HJ, Kim JH, Ohno H, Kim CK: Erythropoietin, 2,3 DPG, oxygen transport capacity, and altitude training in adolescent Alpine skiers. Aviat Space Envir Md 2012, 83:50-53.

90. Christoulas K, Karamouzis M, Mandroukas K: "Living high - training low" vs. "living high - training high": erythropoietic responses and performance of adolescent cross-country skiers. J Sport Med Phys Fit 2011, 51:74-81.

91. Goetze O, Schmitt J, Spliethoff K, Theurl I, Weiss G, Swinkels DW, Tjalsma H, Maggiorini M, Krayenbuhl P, Rau M, Fruehauf H, Wojtal KA, Müllhaupt B, Fried M, Gassmann M, Lutz T, Geier A: Adaptation of iron transport and metabolism to acute high-altitude hypoxia in mountaineers. Hepatology 2013, 58:2153-2162

92. Peyssonnaux C, Zinkernagel AS, Schuepbach RA, Rankin E, Vaulont S, Haase VH, Nizet $\mathrm{V}$, Johnson RS: Regulation of iron homeostasis by the hypoxia-inducible transcription factors (HIFs). J Clin Invest 2007, 117:1926-1932.

93. Volke M, Gale DP, Maegdefrau U, Schley G, Klanke B, Bosserhoff AK, Maxwell $\mathrm{PH}$, Eckardt KU, Warnecke C: Evidence for a lack of a direct transcriptional 
suppression of the iron regulatory peptide hepcidin by hypoxia-inducible factors. PloS One 2009, 4:e7875.

94. Haase VH: Hypoxic regulation of erythropoiesis and iron metabolism. Am J Physiol-Renal 2010, 299:F1-13.

95. Liu Q, Davidoff O, Niss K, Haase VH: Hypoxia-inducible factor regulates hepcidin via erythropoietin-induced erythropoiesis. J Clin Invest 2012, 122:4635-4644.

96. Silvestri L, Pagani A, Camaschella C: Furin-mediated release of soluble hemojuvelin: a new link between hypoxia and iron homeostasis. Blood 2008, 111:924-931

97. Lakhal S, Schodel J, Townsend AR, Pugh CW, Ratcliffe PJ, Mole DR: Regulation of type II transmembrane serine proteinase TMPRSS6 by hypoxia-inducible factors: new link between hypoxia signaling and iron homeostasis. J Biol Chem 2011, 286:4090-4097.

98. Lin L, Goldberg YP, Ganz T: Competitive regulation of hepcidin mRNA by soluble and cell-associated hemojuvelin. Blood 2005, 106:2884-2889.

99. Babitt JL, Huang FW, Xia Y, Sidis Y, Andrews NC, Lin HY: Modulation of bone morphogenetic protein signaling in vivo regulates systemic iron balance. J Clin Invest 2007, 117:1933-1939.

100. McClung JP: Iron status and the female athlete. J Trace Elem Med Biol 2012, 26:124-126

101. Ganz T, Olbina G, Girelli D, Nemeth E, Westerman M: Immunoassay for human serum hepcidin. Blood 2008, 112:4292-4297.

102. Ikeda Y, Tajima S, Izawa-Ishizawa Y, Kihira Y, Ishizawa K, Tomita S, Tsuchiya K, Tamaki T: Estrogen regulates hepcidin expression via GPR30-BMP6dependent signaling in hepatocytes. PloS One 2012, 7:e40465.

103. Guo W, Bachman E, Li M, Roy CN, Blusztajn J, Wong S, Chan SY, Serra C, Jasuja R, Travison TG, Muckenthaler MU, Nemeth E, Bhasin S: Testosterone administration inhibits hepcidin transcription and is associated with increased iron incorporation into red blood cells. Aging Cell 2013, 12:280-291

104. Latour C, Kautz L, Besson-Fournier C, Island ML, Canonne-Hergaux F, Loreal O, Ganz T, Coppin H, Roth MP: Testosterone perturbs systemic iron balance through activation of EGFR signaling in the liver and repression of hepcidin. Hepatology 2014, 59:683-694.

105. Park CH, Valore EV, Waring AJ, Ganz T: Hepcidin, a urinary antimicrobial peptide synthesized in the liver. J Biol Chem 2001, 276:7806-7810.

106. Swinkels DW, Girelli D, Laarakkers C, Kroot J, Campostrini N, Kemna EH Tjalsma H: Advances in quantitative hepcidin measurements by time-of-flight mass spectrometry. PloS One 2008, 3:e2706.

107. Kroot JJ, Laarakkers CM, Geurts-Moespot AJ, Grebenchtchikov N, Pickkers P, van Ede AE, Peters HP, van Dongen-Lases E, Wetzels JF, Sweep FC, Tjalsma $H$, Swinkels DW: Immunochemical and mass-spectrometry-based serum hepcidin assays for iron metabolism disorders. Clin Chem 2010, 56:1570-1579

108. Bansal SS, Abbate V, Bomford A, Halket JM, Macdougall IC, Thein SL, Hider RC: Quantitation of hepcidin in serum using ultra-high-pressure liquid chromatography and a linear ion trap mass spectrometer. Rapid Commun Mass Spectrom 2010, 24:1251-1259.

109. Laarakkers CM, Wiegerinck ET, Klaver S, Kolodziejczyk M, Gille H, Hohlbaum AM, Tjalsma H, Swinkels DW: Improved mass spectrometry assay for plasma hepcidin: detection and characterization of a novel hepcidin isoform. PloS One 2013, 8:e75518.

110. Busbridge M, Griffiths C, Ashby D, Gale D, Jayantha A, Sanwaiya A, Chapman RS: Development of a novel immunoassay for the iron regulatory peptide hepcidin. Brit J Biomed Sci 2009, 66:150-157.

111. Schwarz P, Strnad P, von Figura G, Janetzko A, Krayenbuhl P, Adler G, Kulaksiz H: A novel monoclonal antibody immunoassay for the detection of human serum hepcidin. J Gastroenterol 2011, 46:648-656.

112. Butterfield AM, Luan P, Witcher DR, Manetta J, Murphy AT, Wroblewski VJ, Konrad RJ: A dual-monoclonal sandwich ELISA specific for hepcidin-25. Clinical chemistry 2010, 56:1725-1732.

113. Garza D, Shrier I, Kohl HW 3rd, Ford P, Brown M, Matheson GO: The clinical value of serum ferritin tests in endurance athletes. Clin J Sport Med 1997, 7:46-53.

114. Mettler S, Zimmermann MB: Iron excess in recreational marathon runners. Eur J Clin Nutr 2010, 64:490-494.

115. Cooke KS, Hinkle B, Salimi-Moosavi H, Foltz I, King C, Rathanaswami P, Winters A, Steavenson S, Begley CG, Molineux G, Sasu BJ: A fully-human anti-hepcidin antibody modulates iron metabolism in both mice and non-human primates. Blood 2013, 122:3054-3061.
116. Fung E, Sugianto P, Hsu J, Damoiseaux R, Ganz T, Nemeth E: High-throughput screening of small molecules identifies hepcidin antagonists. Mol Pharmacol 2013, 83:681-690.

117. Schwoebel F, van Ejik LT, Zboralski D, Sell S, Buchner K, Maasch C, Purschke WG, Humphrey M, Zollner S, Eulberg D, Morich F, Pickkers P, Klussmann S: The effects of the anti-hepcidin Spiegelmer NOX-H94 on inflammation-induced anemia in cynomolgus monkeys. Blood 2013, 121:2311-2315.

118. Gaudard A, Varlet-Marie E, Bressolle F, Audran M: Drugs for increasing oxygen and their potential use in doping: a review. Sports Med 2003, 33:187-212.

119. John MJ, Jaison V, Jain K, Kakkar N, Jacob JJ: Erythropoietin use and abuse. Indian J Endocrinol Metabol 2012, 16:220-227.

120. Kong WN, Zhao SE, Duan XL, Yang Z, Qian ZM, Chang YZ: Decreased DMT1 and increased ferroportin 1 expression is the mechanisms of reduced iron retention in macrophages by erythropoietin in rats. J Cell Biochem 2008, 104:629-641

121. Piloto N, Teixeira HM, Teixeira-Lemos E, Parada B, Garrido P, Sereno J, Pinto R, Carvalho L, Costa E, Belo L, Santos-Silva A, Teixeira F, Reis F: Erythropoietin promotes deleterious cardiovascular effects and mortality risk in a rat model of chronic sports doping. Cardiovasc Toxicol 2009, 9:201-210.

122. Nishimoto N, Kanakura Y, Aozasa K, Johkoh T, Nakamura M, Nakano S, Nakano N, Ikeda Y, Sasaki T, Nishioka K, Hara M, Taguchi H, Kimura Y, Kato Y, Asaoku H, Kumagai S, Kodama F, Nakahara H, Hagihara K, Yoshizaki K, Kishimoto T: Humanized anti-interleukin-6 receptor antibody treatment of multicentric Castleman disease. Blood 2005, 106:2627-2632.

123. Song SN, Tomosugi N, Kawabata H, Ishikawa T, Nishikawa T, Yoshizaki K: Down-regulation of hepcidin resulting from long-term treatment with an anti-LL-6 receptor antibody (tocilizumab) improves anemia of inflammation in multicentric Castleman disease. Blood 2010, 116:3627-3634.

124. Zhang SP, Wang Z, Wang LX, Liu SJ: AG490: an inhibitor of hepcidin expression in vivo. World J Gastroenterol 2011, 17:5032-5034.

125. Shin DY, Chung J, Joe Y, Pae HO, Chang KC, Cho GJ, Ryter SW, Chung HT: Pretreatment with CO-releasing molecules suppresses hepcidin expression during inflammation and endoplasmic reticulum stress through inhibition of the STAT3 and CREBH pathways. Blood 2012, 119:2523-2532.

126. van de Vosse $E$, van Agtmael MA: Targets of anticytokine therapy and the risk of infections in humans and mice. Curr Opin Rheumatol 2007, 19:626-635.

127. Theurl I, Schroll A, Sonnweber T, Nairz M, Theurl M, Willenbacher W, Eller K, Wolf D, Seifert M, Sun CC, Babitt JL, Hong CC, Menhall T, Gearing P, Lin HY, Weiss GA: Pharmacologic inhibition of hepcidin expression reverses anemia of chronic inflammation in rats. Blood 2011, 118:4977-4984.

128. Yu PB, Hong CC, Sachidanandan C, Babitt JL, Deng DY, Hoyng SA, Lin HY, Bloch KD, Peterson RT: Dorsomorphin inhibits BMP signals required for embryogenesis and iron metabolism. Nat Chem Biol 2008, 4:33-41.

129. Poli M, Girelli D, Campostrini N, Maccarinelli F, Finazzi D, Luscieti S, Nai A, Arosio P: Heparin: a potent inhibitor of hepcidin expression in vitro and in vivo. Blood 2011, 117:997-1004.

doi:10.1186/2045-3701-4-19

Cite this article as: Kong et al:: Hepcidin and sports anemia. Cell \& Bioscience 2014 4:19

\section{Submit your next manuscript to BioMed Central and take full advantage of:}

- Convenient online submission

- Thorough peer review

- No space constraints or color figure charges

- Immediate publication on acceptance

- Inclusion in PubMed, CAS, Scopus and Google Scholar

- Research which is freely available for redistribution 